\title{
Quantitative Contributions of the Sources, Contamination and Ecological Risk of Heavy Metals in Soils from a Closed Coal Mine of Huaibei Coalfield, Eastern China
}

\author{
Jiying Xu ${ }^{1}$, Herong Gui ${ }^{1 *}$, Hongxia Fang ${ }^{2}$, Hongbao Dai ${ }^{3}$, Yan Guo ${ }^{1}$, Jiayu Chen ${ }^{2}$, \\ Chen $\mathrm{Li}^{2}$, Chen Chen'², Chunlei Wang \\ ${ }^{1}$ School of Resources and Civil Engineering, Suzhou University, Suzhou, 234000 Anhui, China \\ ${ }^{2}$ School of Earth and Environment, Anhui University of Science and Technology, Huainan, 232001, Anhui, China \\ ${ }^{3}$ School of Environment and Surveying and Mapping Engineering, Suzhou University, Suzhou, 234000, Anhui, China
}

Received: 22 November 2020

Accepted: 25 January 2021

\begin{abstract}
With the increasing number of closed mines, the geological environment problems around closed mines have become increasingly prominent, especially in terms of soil pollution. In this paper, a total of 32 topsoil samples were collected from Qianling closed coal mine and the contents of $\mathrm{Cu}, \mathrm{Zn}, \mathrm{Co}$, $\mathrm{Cr}, \mathrm{Mn}, \mathrm{As}, \mathrm{Cd}$ and $\mathrm{Pb}$ were analyzed. The results indicated that the contents $\mathrm{Zn}$ and $\mathrm{As}$ exceeded the surface soil background values of Anhui Province. Compared with the soil of production mines, the contents of $\mathrm{Pb}$ and $\mathrm{Zn}$ were higher. The assessment results of pollution and ecological risk of soil based on Nemerow index, Geological accumulation index and potential ecological risk assessment method showed that the closed coal mine was in the mild to moderate pollution and mild hazard ecological risk. The Pearson correlation and positive matrix decomposition model were applied to identify the sources of soil heavy metals, which included atmospheric dustfall (22.47\%), natural factors (22.51\%), agricultural activities (4.40\%), transportation (8.90\%) and industrial emissions (42.08\%), respectively.
\end{abstract}

Keywords: source analysis, ecological risk, soil heavy metals, closed coal mine, quantitative contributions

\section{Introduction}

China's energy structure was low in oil and gas, and relatively rich coal. Coal had always held

*e-mail: guiherong@163.com a dominant position in China's primary energy, and this situation can not be changed for a long time [12]. Due to the long-term high-intensity mining of coal resources in China, some old mining areas tended to be exhausted and closed [3]. It was estimated that by 2030, the number of closed/abandoned mines in China will reach 15000 [4]. During the mining, selection by washing, storage and transportation of coal resources, 
some pollutants (such as waste water, coal dust and coal gangue, etc.) were easily discharged into the surrounding environment. The pollutants entered the soil through runoff, sedimentation and leaching, which would lead to the enrichment of heavy metals in the soil of the coal mine area [5], resulting in the soil around the closed/abandoned mine safety and environmental issues [6]. Once the soil was contaminated by heavy metals, it would not only inhibit and poison the growth and development of plants, but also had a serious impact on the closure of the originally fragile ecological environment around coal mining areas. It may also endanger human health through the food chain and restrict local economic development [7].

In recent years, predecessors have carried out a large number of studies on heavy metal pollution and environmental effects of coal mine soil, which mainly focus on the content characteristics of heavy metals in coal mine soil, pollution (impact) assessment [8-11], spatial differentiation [12-13], enrichment characteristics [14-15] and pollution source analysis etc. The method of soil pollution source analysis is considered a central issue and it is essential to select appropriate approaches to identify the source. Several approaches that integrated by Unmix model, Ensemble model, Isotropic model and
PMF model [16-18]. In general, the authors have mostly studied soil heavy metal pollution on production coal mines, and relatively few studies on closed/abandoned mines.

The purpose of the present study was to provide scientific basis for environmental supervision, early warning and treatment of soil in closed mining area, which using quantitative contributions of the sources, contamination and ecological risk of heavy metals.

\section{Materials and Methods}

\section{General Situation of the Study Area}

The Qianling Coal Mine was located in the Huaibei coal field of northern Anhui Province. It was built in 1971 and put into operation in 1983. It had a design capacity of 300,000 tons of raw coal per year [19] The mine was closed in August 2015. The regional profile and the location of the study area were shown in Fig. 1a) and Fig. 1b).

The soil types in the study area were mainly tidal soil, mortar black soil, silt black soil, green loess, etc.

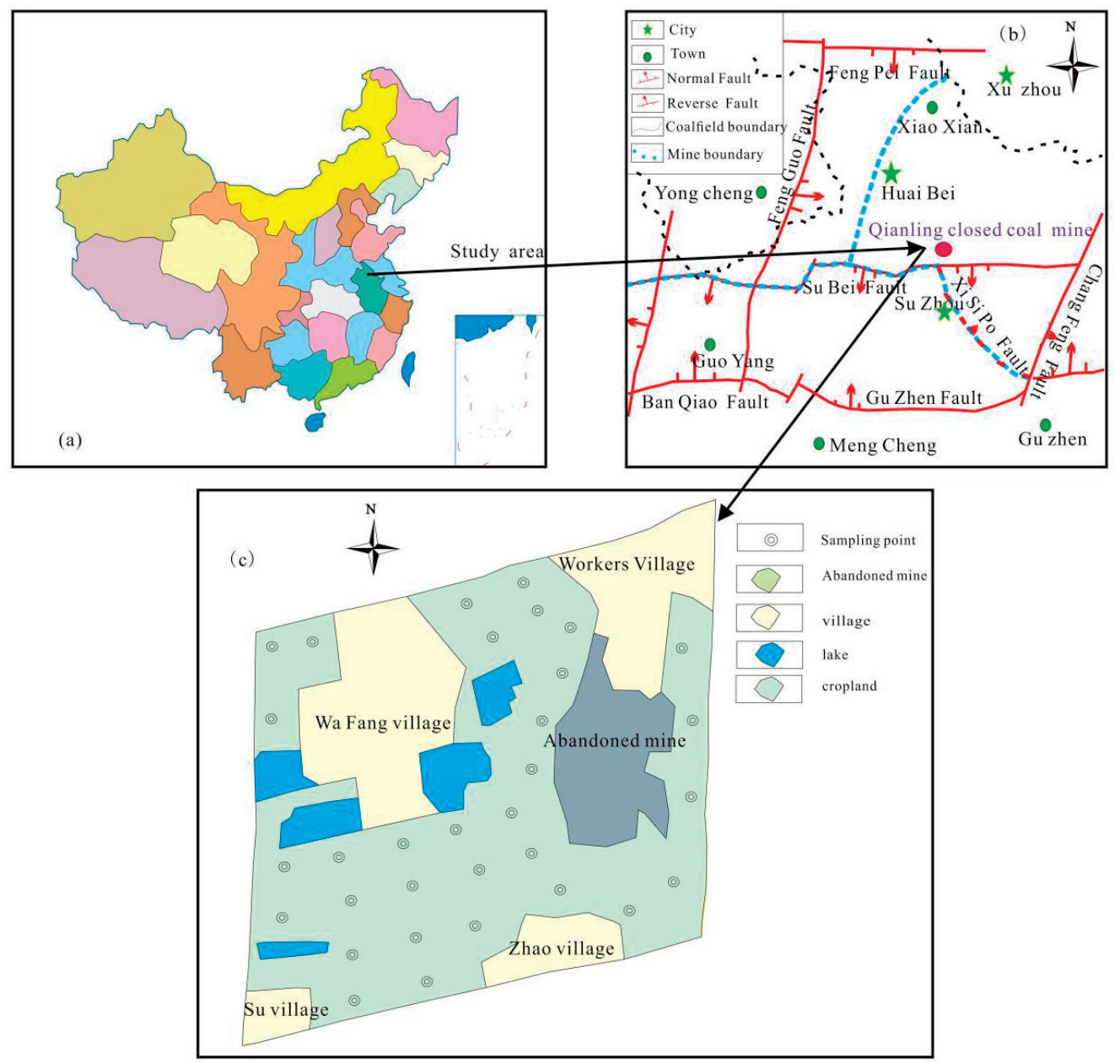

Fig. 1. Geographical location and sampling point distribution map of the study area. 
The soil organic matter content was low, the structure was poor, and the arable property was good, which belonged to the loose accumulation layer of Cenozoic. The study area had four distinct seasons, mild climate and suitable rainfall. It had the typical warm zone and semi-humid monsoon climate characteristics of midlatitude regions. The rainfall was mainly concentrated in summer, and the winter was dry. The temperature changed greatly in spring and autumn. The annual distribution of rainfall was uneven, mainly concentrated in July to September, accounting for $75 \%$ of the annual precipitation. The dominant wind direction in summer was southeast wind, and the dominant wind direction in winter was northeast wind [20].

\section{Sample Collection, Processing and Testing}

The grid distribution method was mainly used for the layout of sampling points, taking into account the surface water system and traffic roads in the mining area. A total of 32 sampling points were arranged. The distribution of sampling points was shown in Fig. 1c). The surface soil of $0-10 \mathrm{~cm}$ was collected with stainless steel shovel, and the surface debris was removed, and then put it into a clean sealing bag, labeled and the sampling point was positioned with GPS instrument. After the samples were transported back to the laboratory, they were dried by natural air, crushed, passed through 60, 80, 100 and 200 mesh wooden nylon sieves in turn, and then the samples were reduced to about $1 \mathrm{~kg}$ by quartering method. The $5 \mathrm{~g}$ soil samples to be measured were accurately weighed by the analytical balance, and the samples to be tested were taken out after being pressed by $20 \mathrm{t}$ tablet press.

The content of $\mathrm{Cu}, \mathrm{Zn}, \mathrm{Co}, \mathrm{Cr}, \mathrm{Mn}, \mathrm{As}, \mathrm{Cd}$, and $\mathrm{Pb}$ elements in the sample was determined by $\mathrm{X}$-ray fluorescence spectrometer (ICP-2000), and the soil component analysis standard material (GBW07430, GSS-16) was detected, and the recovery rate ranged from $86 \%$ to $115 \%$, the relative deviation between samples is $<5 \%$, and the test results met the quality control requirements.
Data Processing and Analysis Methods

\section{Statistical Analysis}

The IBM SPSS statistics 19.0 software was used to process and analyze the data, including descriptive statistical analysis of heavy metal elements and Pearson correlation analysis. The EpaPMF5.0 software was used to analyze the sources of heavy metals in soil. The box diagram and histogram were drawn by Origin 8.0 software.

\section{Pollution Assessment Method}

Nemero Comprehensive Pollution Index Method

Nemero comprehensive pollution index method takes into account the average value and maximum value of single factor pollution index. It is an evaluation method that comprehensively considers the impact of various metals in soil on environmental quality [21-23]. Its calculation formulas are (1) and (2). The evaluation standard of pollution degree is shown in Table 1.

$$
\begin{gathered}
P_{i}=C_{i} / S_{i} \\
P_{n}=\sqrt{\frac{\left(P_{i, \text { ave }}\right)^{2}+\left(P_{i, \max }\right)^{2}}{2}}
\end{gathered}
$$

...where $P_{i}$ is a single environmental quality index; $P_{n}$ represents the Nemeiro comprehensive pollution index; $C_{i}$ is the measured element content; $S_{i}$ is the element reference standard content; $P_{\text {iave }}$ is the average value of the element environmental quality index of the sampling point; $P_{i, \max }$ is the maximum value of the environmental quality index of the sampling point.

\section{Geological Accumulation Index Method}

The Geological accumulation index was proposed by the German scientist Muller in 1969 to quantitatively evaluate the degree of heavy metal pollution in sediments [24]. The classification standard of heavy

Table 1. Classification Standard of soil heavy metal pollution.

\begin{tabular}{|c|c|c|c|c|c|c|c|c|c|}
\hline \multicolumn{2}{|c|}{ Geological accumulation } & \multicolumn{3}{|c|}{ Nemero comprehensive pollution } & \multicolumn{5}{c|}{ Potential ecological hazard } \\
\hline$I_{\text {geo }}$ & Level & $P_{i}$ & Level & $P_{n}$ & Level & $E_{r}^{i}$ & Level & $R I$ & Level \\
\hline$\leq 0$ & Non & $\leq 1$ & Clean & $\leq 0.7$ & Clean & $<40$ & Mild & $<150$ & Mild \\
\hline $0 \sim 1$ & Non-Mild & $1 \sim 2$ & Mild & $0.7 \sim 1$ & Warning line & $40 \sim 80$ & Moderate & $150 \sim 300$ & Moderate \\
\hline $1 \sim 2$ & Mild & $2 \sim 3$ & Moderate & $1 \sim 2$ & Mild & $80 \sim 160$ & Strong & $300 \sim 600$ & Strong \\
\hline $2 \sim 3$ & Mild-Strong & $>3$ & Serious & $2 \sim 3$ & Moderate & $160 \sim 320$ & Very Strong & $\geq 600$ & Very Strong \\
\hline $3 \sim 4$ & Strong-Extreme & & & $>3$ & Serious & $\geq 320$ & Extreme Strong & & \\
\hline$>5$ & Extreme & & & & & & & & \\
\hline
\end{tabular}


metal pollution is shown in Table 1 , and the calculation formula is (3).

$$
I_{\text {geo }}=\log _{2}\left[C_{n} / K \bullet B_{n}\right]
$$

...where $C_{n}$ is the content of the element in the soil; $B_{n}$ is the reference value of the element. In this study, the soil background value of Anhui Province is taken as the reference value [25], and $\mathrm{K}$ represents the variation coefficient of background value caused by diagenesis (generally $\mathrm{K}=1.5$ ).

\section{Potential Ecological Hazard Index Method}

The potential ecological risk index was used to evaluate the potential risk, ecological sensitivity and toxicity of heavy metal concentration, reflecting the pollution degree of single pollutant and even the pollution level of mixed pollutants [26]. The formula is (4).

$$
R I=\sum_{i=1}^{n} E_{r}^{i}=\sum_{i=1}^{n} T_{r}^{i} C_{r}^{i}=\sum_{i=1}^{n} T_{r}^{i} C_{o}^{i} / C_{n}^{i}
$$

...where $R I$ is the potential ecological hazard index of multiple heavy metals; $E_{r}{ }^{i}$ represents the potential ecological hazard index of a single heavy metal; $C_{o}{ }^{i}$ means the actual measured value of elements; $C_{n}{ }^{i}$ is the reference value of elements; $T_{r}^{i}$ represents the toxicity response coefficient of elements.

\section{Pollution Source Analysis Method}

Positive matrix decomposition is a multi-element analysis technique that decomposes sample data into two matrices of factor contribution and factor distribution. Its main advantage is to correlate the sample size and estimated uncertainty with the sample data to weight a single point, and to easily manage missing data [27]. The PMF model uses the weighted least squares method to limit and iteratively calculate, and continuously decompose the matrix. The optimization goal is to minimize the objective function. The calculation formulas for the minimum value of the objective function $\mathrm{Q}$ are (5) and (6).

$$
\begin{gathered}
Q=\sum_{i=1}^{n} \sum_{j=1}^{m}\left(\frac{x_{i j}-\sum_{k=1}^{p} g_{i k} f_{k j}^{2}}{u_{i j}}\right) \\
X_{i j}=\sum_{k=1}^{p} g_{i k} f_{k j}+e_{i j}
\end{gathered}
$$

In addition, the establishment of the PMF model requires the uncertainty $u_{i j}$ of the sample species concentration, and the calculation formulas are (7) and (8).

$$
\text { When } \mathrm{c} \leq \mathrm{MDL}, u_{i j}=5 / 6 \times M D L
$$

When $\mathrm{c}>$ MDL, $u_{i j}=\sqrt{(E F \times c)^{2}+(0.5 \times M D L)^{2}}$

...where $c$ is the concentration of elements in the sample; $M D L$ is the detection limit of the determination method; $E F$ is the determination precision.

\section{Results and Discussion}

\section{Characteristics of Soil Heavy Metal Content}

The statistical characteristics of the contents of $\mathrm{Cu}, \mathrm{Zn}, \mathrm{Co}, \mathrm{Cr}, \mathrm{Mn}, \mathrm{As}, \mathrm{Cd}$, and $\mathrm{Pb}$ of the 32 soil samples were listed in Table 2. It can be seen that the order of the average content of heavy metals in the study area was $\mathrm{Mn}>\mathrm{Zn}>\mathrm{Pb}>\mathrm{Cr}>\mathrm{As}>\mathrm{Cu}>\mathrm{Co}>\mathrm{Cd}$. Except the average contents of $\mathrm{Cu}, \mathrm{Co}$, and $\mathrm{Cr}$ were lower than the background values of Anhui Province, the average contents of $\mathrm{Zn}, \mathrm{Mn}, \mathrm{As}, \mathrm{Cd}$, and $\mathrm{Pb}$ were $89.37 \mathrm{mg} / \mathrm{kg}, 544.29 \mathrm{mg} / \mathrm{kg}, 12.63 \mathrm{mg} / \mathrm{kg}, 0.10 \mathrm{mg} / \mathrm{kg}$, $31.90 \mathrm{mg} / \mathrm{kg}$, exceeding the soil background values of Anhui Province, respectively 1.44, 1.03, 1.40, 1.03 , and 1.20 times, indicating that these heavy metals had accumulated different degrees of pollution accumulation, including $\mathrm{Mn}$ and $\mathrm{Cd}$ relatively were low, $\mathrm{Pb}$, As and $\mathrm{Zn}$ were relatively high. Compared with the soil pollution risk screening value of the currently piloted "Soil Environmental Quality-Agricultural Land Soil Pollution Risk Control Standard GB15618-2018" [28], the average values of $\mathrm{Cu}, \mathrm{Zn}, \mathrm{Co}, \mathrm{Cr}, \mathrm{Mn}$ and $\mathrm{Cd}$ were all lower than the soil pollution risk screening value except for the $\mathrm{Pb}$ exceeding standard.

The coefficient of variation can reflect the degree of dispersion of the data. According to Wilding's classification of the degree of variation [29], it could be seen that $\mathrm{Zn}, \mathrm{Mn}$, and As (35.64\%, 21.05\%, 34.31\%) were moderate variations $(15 \%<\mathrm{CV}<36 \%) ; \mathrm{Cu}, \mathrm{Co}$, Cd (175.68\%, 91.52\%, 45.86\%) were high variance $(\mathrm{CV}>36 \%)$; $\mathrm{Cr}(9.31 \%)$ was low variance $(\mathrm{CV}<15 \%)$.

\section{Comparative Analysis of Soil Heavy Metals Content with Production Mining Area}

It could be seen from Table 3 that the contents of $\mathrm{Zn}$, As and $\mathrm{Pb}$ in the soil of closed mine were higher than those of local ordinary cultivated land [30]. In the study area, the average contents of $\mathrm{Zn}, \mathrm{Cr}, \mathrm{Cu}$, and $\mathrm{Cd}$ were basically consistent with the results of the study on soil heavy metals in the Sunan mining area [31] (production mining area) and Linhuan mining area [32] (production mining area), and the order of contents was $\mathrm{Zn}>\mathrm{Cr}>\mathrm{Cu}>\mathrm{Cd}$, and compared with the heavy metals in the wasteland of Sudong mining area [33] (production mining area), $\mathrm{Cr}, \mathrm{Zn}, \mathrm{Pb}$ are in different order from $\mathrm{As}$ and $\mathrm{Cu}$. Compared with the soil in Sudong, Sunan and 
Table 2. Statistical characteristics of heavy metal content in soil samples.

\begin{tabular}{|c|c|c|c|c|c|c|}
\hline Element & $\begin{array}{c}\text { Range } \\
\left(\mathrm{mg} \cdot \mathrm{kg}^{-1}\right)\end{array}$ & $\begin{array}{c}\text { Mean } \\
\left(\mathrm{mg} \cdot \mathrm{kg}^{-1}\right)\end{array}$ & $\begin{array}{c}\text { Standard deviation } \\
\left(\mathrm{mg} \cdot \mathrm{kg}^{-1}\right)\end{array}$ & $\begin{array}{c}\text { Coefficient of } \\
\text { variation/(\%) }\end{array}$ & $\begin{array}{c}\text { Background values of } \\
\text { Anhui Province } \\
\left(\mathrm{mg} \cdot \mathrm{kg}^{-1}\right)\end{array}$ & $\begin{array}{c}\text { Chinese soil pollution } \\
\text { risk screening } \\
\text { values } /\left(\mathrm{mg} \cdot \mathrm{kg}^{-1}\right)\end{array}$ \\
\hline $\mathrm{Cu}$ & $0.58 \sim 46.39$ & 5.53 & 9.72 & $175.68 \%$ & 20.4 & 100.00 \\
\hline $\mathrm{Zn}$ & $53.65 \sim 235.93$ & 89.37 & 31.85 & $35.64 \%$ & 62.00 & 250.00 \\
\hline $\mathrm{Co}$ & $0.55 \sim 19.15$ & 3.25 & 2.97 & $91.52 \%$ & 16.30 & - \\
\hline $\mathrm{Cr}$ & $23.58 \sim 37.57$ & 31.75 & 2.95 & $9.31 \%$ & 66.50 & - \\
\hline $\mathrm{Mn}$ & $296.34 \sim 977.31$ & 544.29 & 114.55 & $21.05 \%$ & 530.00 & 30.00 \\
\hline $\mathrm{As}$ & $5.37 \sim 20.92$ & 12.63 & 4.33 & $34.31 \%$ & 9.00 & 0.00 \\
\hline $\mathrm{Cd}$ & $0.03 \sim 0.20$ & 0.10 & 0.04 & $45.86 \%$ & 0.097 & 120 \\
\hline $\mathrm{Pb}$ & $23.36 \sim 46.98$ & 31.90 & 4.16 & $13.04 \%$ & 26.60 & 20 \\
\hline
\end{tabular}

Table 3. Comparison of heavy metals content with production coal mine $\left(\mathrm{mg} \cdot \mathrm{kg}^{-1}\right)$.

\begin{tabular}{|c|c|c|c|c|c|c|c|c|c|}
\hline Area & $\mathrm{Cu}$ & $\mathrm{Zn}$ & $\mathrm{Co}$ & $\mathrm{Cr}$ & $\mathrm{Mn}$ & $\mathrm{As}$ & $\mathrm{Cd}$ & $\mathrm{Pb}$ & Literature sources \\
\hline Study area (closed) & 5.53 & 89.37 & 3.25 & 31.75 & 544.29 & 12.63 & 0.10 & 31.90 & This study \\
\hline Local cultivated land & 22.12 & 57.63 & - & 67.70 & - & 9.71 & 0.13 & 17.58 & {$[30]$} \\
\hline Southern-Su ( production ) & 28.78 & 65.43 & - & 50.89 & 555.30 & - & 0.28 & 12.48 & {$[31]$} \\
\hline Eastern-Su ( production ) & 26.16 & 63.68 & 9.12 & 69.33 & 457.74 & 14.99 & 0.08 & 28.99 & {$[32]$} \\
\hline Linhuan ( production ) & 24.77 & 60.25 & & 50.02 & & & 0.28 & 27.10 & {$[33]$} \\
\hline
\end{tabular}

Linhuan mining areas, it is found that the closed mines had lower $\mathrm{Cu}$ and $\mathrm{Cr}$, and significantly higher $\mathrm{Pb}$ and $\mathrm{Zn}$ contents. It was estimated that there were $\mathrm{Pb}$ and $\mathrm{Zn}$ pollution in the surface soil of the closed mine.

Liu [9] et al. analyzed the heavy metals in the soil of the East Coal Field and showed that the content of heavy metals in the soil around the coal mine was affected by mining years, coal combustion, wind direction, topography, slope direction, soil texture and human activities. The closed coal mine was an old mining area with long mining activities and significant accumulation of heavy metals. The soil in this mining area was dominated by fluvo-aquic soil and sand ginger black soil, with heavy texture, poor permeability, low degree of heavy metal leaching, and more heavy metals attached to it. Considering that the closed mine is located in the Huaibei coal field, the terrain was flat, and the influence of terrain and slope can be basically ignored. The mining years, soil texture, wind direction and human activities had a significant impact on the distribution of heavy metal content in the closed mine.

\section{Assessment of Soil Heavy Metal Pollution}

Based on the background values of surface soil in Anhui Province, the Geological accumulation index, Nemerow comprehensive index and potential ecological hazard index of soil samples in the study area were calculated.
According to Table 1, the Nemerow index of all elements in the sample were greater than 0 , in which the Nemerow index of $\mathrm{Cr}$ was 0.52 , ranging from 0 to 0.72 , which belonged to the clean; $\mathrm{Cu}$, as, $\mathrm{Cd}, \mathrm{Pb}, \mathrm{Mn}$, Co exceeded the warning line and were in the light pollution level, in which the Nemerow index of $\mathrm{Zn}$ was the highest of 2.88 , belonging to moderate pollution. The Nemerow indexes were ranked as $\mathrm{Zn}$ (2.88) $>\mathrm{As} \quad(1.92)>\mathrm{Cd}=\mathrm{Cu} \quad(1.62)>\mathrm{Pb} \quad(1.51)>\mathrm{Mn} \quad(1.49)>\mathrm{Co}$ $(0.84)>\mathrm{Cr}(0.52)$, as shown in Fig. 2 .

According to the classification standard of pollution level in Table 1 and formula (3), the Geological accumulation index of $\mathrm{Co}$ and $\mathrm{Cr}$ were less than 0 , and they were in a Non-pollution state, indicating that the pollution risk of heavy metal elements in Co and $\mathrm{Cr}$ was low; $\mathrm{Zn}$, As, Cd had a certain level of accumulation, in which $\mathrm{Zn}$ was in Non-pollution, NonMild and Mild pollution state, and the proportions of sample points accounted for $78.13 \%, 18.75 \%$, and $3.13 \%$ of the total number of samples respectively. The pollution contribution of As was $46.88 \%$, and that of $\mathrm{Cd}$ was $15.63 \%$. The pollution levels of As and $\mathrm{Cd}$ belonged to Non-Mild level. For $\mathrm{Pb}, \mathrm{Cu}$ and $\mathrm{Mn}$, only one abnormal sample point was in Non-Mild pollution level, and the rest were Non-pollution, as shown in Fig. 3. From the average value of the Geological accumulation index, the pollution degree of heavy metal elements on the soil around the closed mine was in order: $\mathrm{Zn}>\mathrm{As}>\mathrm{Pb}>\mathrm{Mn}>\mathrm{Cd}>\mathrm{Cr}>\mathrm{Co}>\mathrm{Cu}$, which 


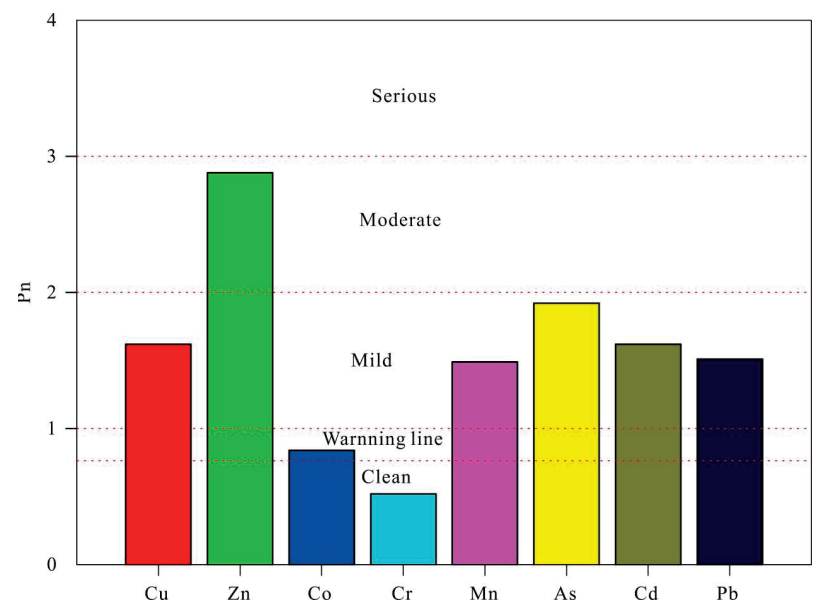

Fig. 2. Histogram of Nemero comprehensive pollution assessment.

was consistent with the analysis results of heavy metal content characteristics, indicating that the pollution accumulation of $\mathrm{Zn}$ and $\mathrm{As}$ in the closed coal mine soil had occurred to a certain extent.

According to Table 1 and formula (4), the potential ecological risk index of $\mathrm{Zn}$, $\mathrm{As}$ and $\mathrm{Pb}$ in $100 \%$ soil samples was in a mild risk state, and $\mathrm{Cd}$ was the most important potential ecological risk factor, with $18.75 \%$ and $81.25 \%$ of soil samples showing moderate and mild hazards respectively (Fig. 4a, Fig. 4b). In general, the potential risk of soil heavy metals to the ecological environment in the study area was at a mild level $(31.60<\mathrm{RI}<92.61)$, as shown in Fig. 4c).

Different evaluation methods have different specific evaluation results. The reason is that Nemeiro index and Geological accumulation index will change due to different evaluation standards, and their results have a linear relationship with the content of heavy metals. Therefore, the two methods are basically consistent with the content analysis results [34]. The potential ecological hazard index is weighted due to the toxic effects of different heavy metals, and the environmental ecological effects are linked with toxicology. The evaluation results will be more focused on toxicological aspects due to the toxicity coefficient. Based on the three evaluation methods, it can be known that the main control objects of heavy metals in the soil of the Qianling closed mine were $\mathrm{Zn}$, As, and $\mathrm{Cd}$, and other heavy metals need to be controlled.

\section{Source Analysis of Soil Heavy Metal Pollution}

\section{Correlation Analysis}

Studies have shown that there was a significant correlation between the contents of heavy metals, which could reflect that each element has the same source or geochemical process [35]. If there was a significant and extremely significant correlation between the elements, it indicated that the elements generally had a certain homologous relationship or belonged to the compound pollution situation.

Table 4 showed Pearson correlation coefficients of 8 heavy metals in surface soil of closed mine. It could be seen from Table 4 that $\mathrm{Mn}-\mathrm{Co}(\mathrm{r}=0.654), \mathrm{Zn}-\mathrm{Cu}$ $(\mathrm{r}=0.520), \mathrm{Pb}-\mathrm{Zn}(\mathrm{r}=0.489)$ and $\mathrm{Pb}-\mathrm{Cu}(\mathrm{r}=0.358)$ had extremely significant positive correlation $(\mathrm{P}<0.01)$, while $\mathrm{Cu}-\mathrm{Mn}(\mathrm{r}=0.332), \mathrm{Cu}-\mathrm{Pb}(\mathrm{r}=0.358)$ and $\mathrm{Zn}-\mathrm{Cr}$ $(r=0.329)$ were positively correlated, indicating that

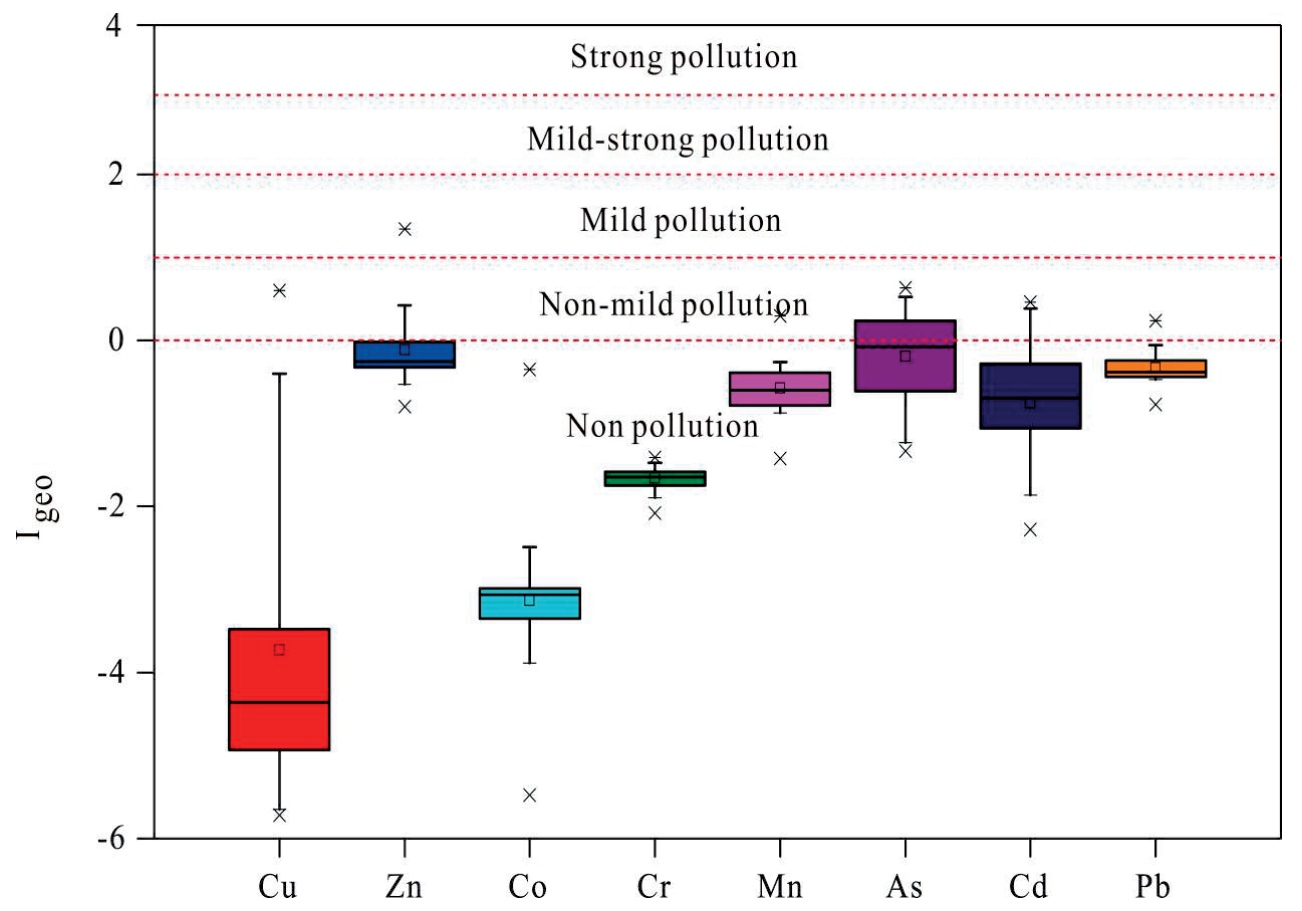

Fig. 3. Box diagram of Geological accumulation index. 

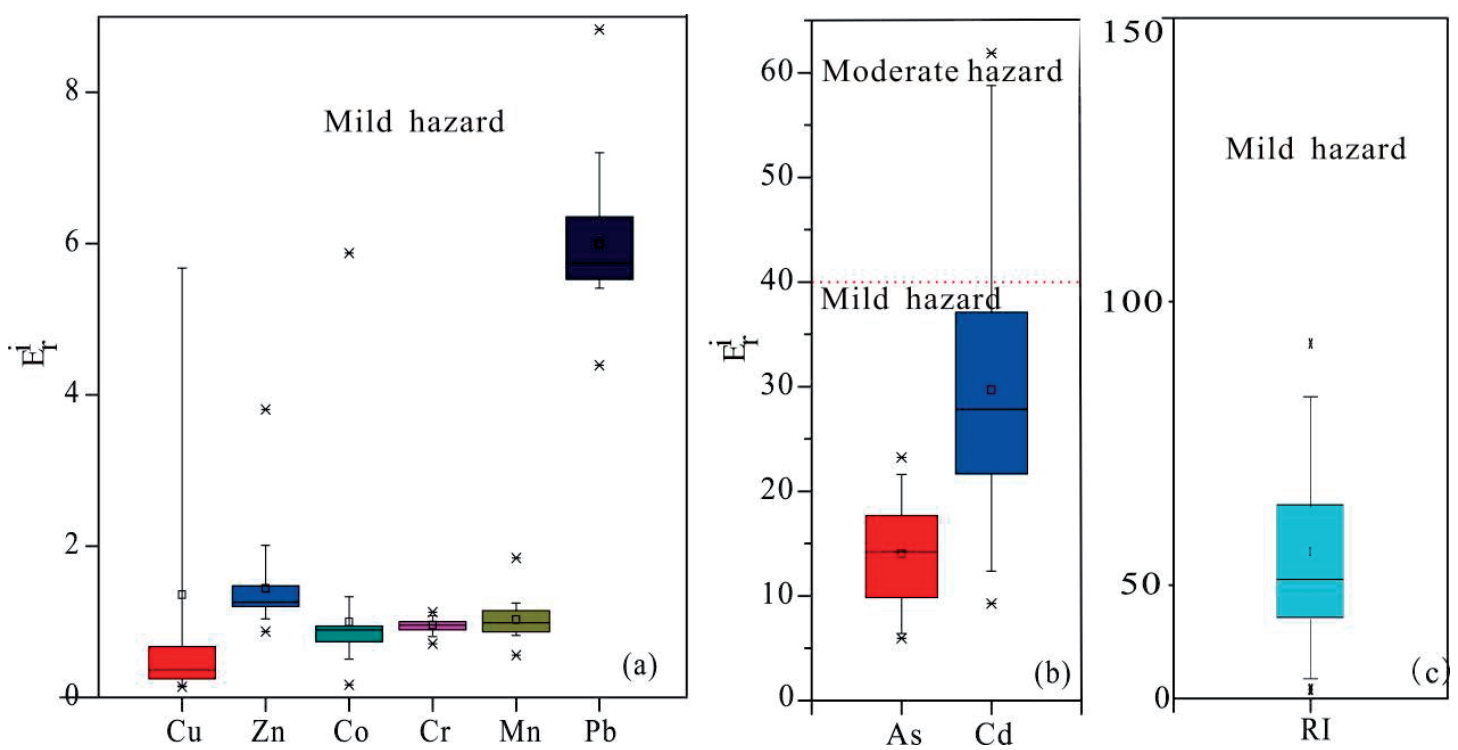

Fig. 4. Box diagram of potential ecological risk assessment.

$\mathrm{Pb}, \mathrm{Zn}$ and $\mathrm{Cu}$ may had the same source or similar geochemical process, while Mn and Co may had the same influence factors. According to the correlation preliminary judgment, the sources of heavy metals in the study area were complex, and different sources of heavy metals need further analysis.

\section{Quantitative Contributions of the Sources Analysis}

In order to further analyze the possible pollution sources of heavy metals in the soil of the closed coal mine, the positive rectangular decomposition (PMF) model was used to analyze heavy metal samples, and the contribution ratio of eight elements was evaluated. The pollution sources and contribution ratios of the eight heavy metals were shown in Fig. 5.

The main load element of factor 1 was As, which the load rate was $57.8 \%$. Other elements had lower load rate (Fig. 5a). When analyzing the sources of heavy metals in Zhundong coal mine soil, scholars pointed out that As mainly came from industrial emissions, coal combustion and transportation [9]. The previous studies on emission characteristics of coal fired boilers showed that As element accounted for $84.6 \%$ of raw coal content in fly dust from coal combustion [36]. The evaluation of heavy metal pollution in farmland soils in the coal mine-affected area of northern Bangladesh found that coal mine dust containing sulfide mineral particles was deposited on the surface and releases As and other toxic elements after oxidation [37]. The atmosphere is an important carrier of natural and man-made pollutants. Atmospheric dust reduction may be an important way for soil heavy metal enrichment. The Coal mine dust and fly ash deposited on the soil surface of mining area for a long time after closing the mine, which caused the accumulation of soil As in mining area. Therefore, factor 1 represented the source of atmospheric dustfall caused by mixed factors.

Table 4. The Pearson correlation analysis between elements.

\begin{tabular}{|c|c|c|c|c|c|c|c|c|}
\hline Elements & $\mathrm{Cu}$ & $\mathrm{Zn}$ & $\mathrm{Co}$ & $\mathrm{Cr}$ & $\mathrm{Mn}$ & $\mathrm{As}$ & $\mathrm{Cd}$ & $\mathrm{Pb}$ \\
\hline $\mathrm{Cu}$ & 1 & & & & & & & \\
\hline $\mathrm{Zn}$ & $.520^{* *}$ & 1 & & & & & & \\
\hline $\mathrm{Co}$ & 0.198 & 0.016 & 1 & & & & & \\
\hline $\mathrm{Cr}$ & 0.09 & 0.329 & 0.112 & 1 & & & & \\
\hline $\mathrm{Mn}$ & 0.332 & -0.084 & $.654^{* *}$ & 0.265 & 1 & & & \\
\hline $\mathrm{As}$ & -0.286 & -0.268 & -0.177 & -0.051 & -0.103 & 1 & & \\
\hline $\mathrm{Cd}$ & -0.01 & 0.056 & 0.037 & 0.209 & -0.014 & 0.271 & 1 & \\
\hline $\mathrm{Pb}$ & $.358^{*}$ & $.489^{* *}$ & -0.198 & -0.231 & -0.126 & -0.289 & -0.213 & 1 \\
\hline
\end{tabular}

** the correlation was significant at 0.01 level (bilateral)

* the correlation was significant at 0.05 level (bilateral) 


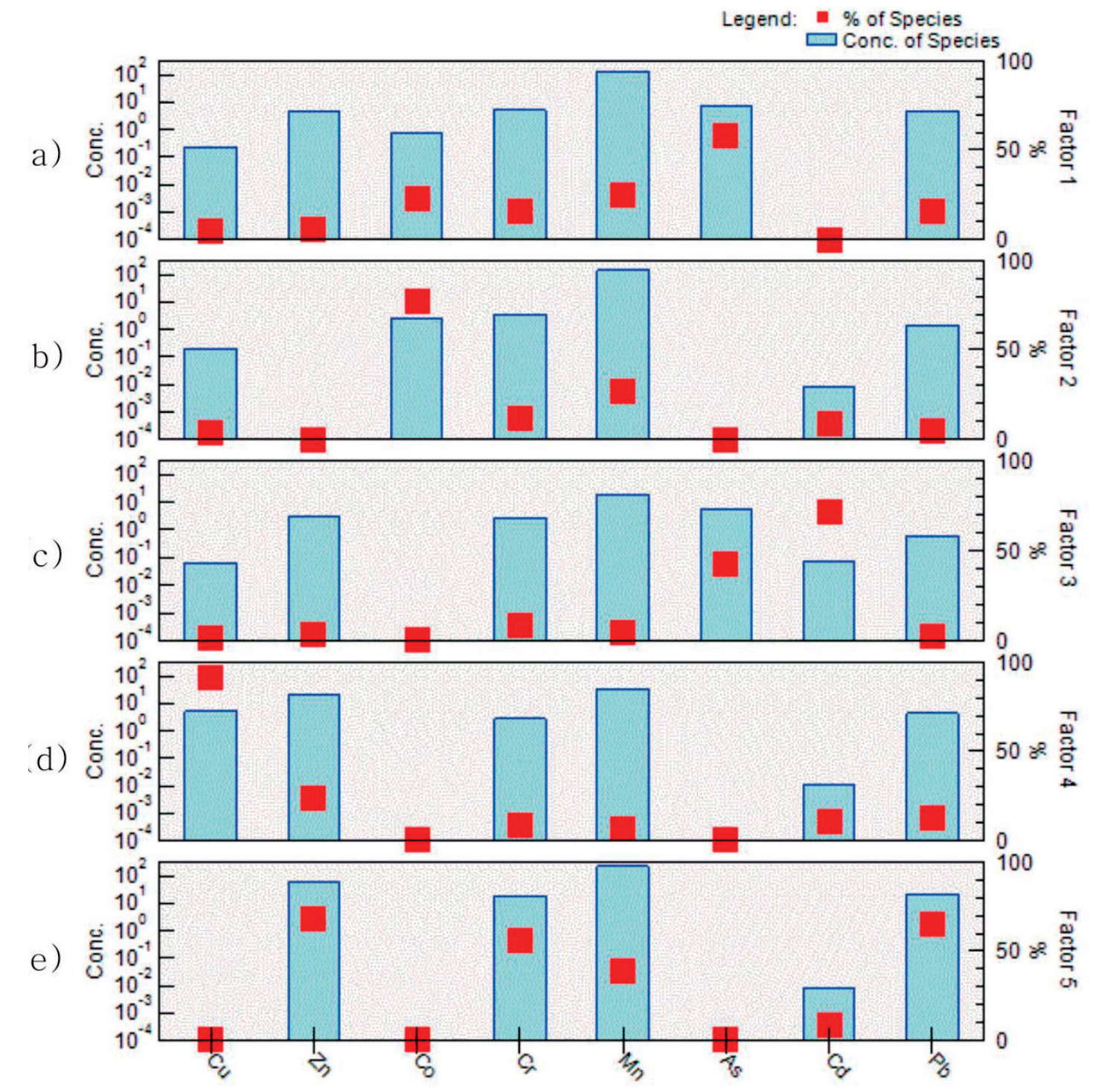

Fig. 5. Source profiles and source contribution of soil heavy metal from PMF.

Factor 2 is dominated by Co (77.6\%) and Mn (26.6\%) (Fig. 5b). The results of heavy metal pollution in the Sudong mining area found that natural factors such as soil parent material were the main source of Co-Mn enrichment [32]. The basic statistical characteristics and correlation analysis of heavy metals in the soil showed that the Co content was lower than the soil background value in Anhui Province and was not polluted. The Mn content exceeded the standard by only 1.03 times, which belonged to mild pollution, and there was a strong positive correlation between $\mathrm{Co}$ and $\mathrm{Mn}$, indicating that natural factors were the main sources of $\mathrm{Co}$ and $\mathrm{Mn}$ in the study area. Therefore, factor 2 resolved to a natural source.

In factor 3, Cd (72.0\%) and As (42.2\%) contributed the most (Fig. 5c). Research on the sources of $\mathrm{Cd}$ in China's soil show that $\mathrm{Cd}$ mainly comes from agricultural production activities [38]. The previous studies have found that $40 \%$ of As in the environment may be related to the natural environment and agricultural activities, and the remaining 60\% was attributed to traffic and industrial emissions [39]. In the actual agricultural production, irrigation and fertilization was an indispensable part of the farmland around the mining area. The use of a large number of chemical fertilizers led to the accumulation of $\mathrm{Cd}$ in the soil. Pollution assessment and correlation analysis showed that $\mathrm{Cd}$ and $\mathrm{As}$ had a certain accumulation level in the soil of closed mining area, and the correlation between $\mathrm{Cd}$ and As was significant. Therefore, factor 3 was resolved as an agricultural pollution source.

The main load elements of factor 4 were $\mathrm{Cu}(90.6 \%)$ and $\mathrm{Zn}$ (23.2\%) ( Fig. 5d). $\mathrm{Cu}$ and $\mathrm{Zn}$ were the main components of motor vehicle emissions [40-42], and the wear of engine components and fuel or gasoline leakage may be the cumulative source of $\mathrm{Cu}$ [43]. As a fuel additive for automobiles, $\mathrm{Zn}$ came from tire wear and road equipment [44], which entered the surface soil through atmospheric dust [45]. The railway and road on the west side of the Qianling closed coal mine was 
Atmospheric dustfall

Natural source

Agricultural pollution

Traffic emission

Industrial emission

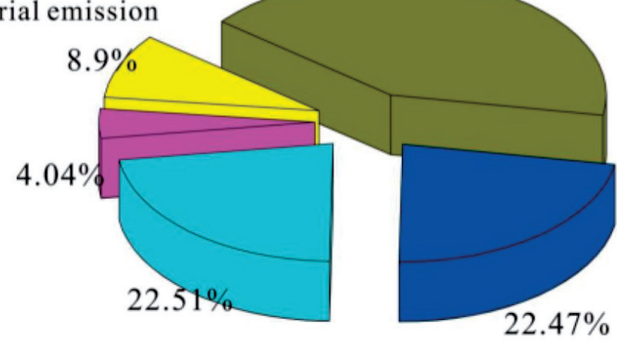

Fig. 6. Pie chart of contribution proportion of pollution sources.

the main hubs of coal transportation. From mining to closure for decades, the frequency of trains and cars was high and the traffic volume was large. Transportation was the main reason for the accumulation of $\mathrm{Cu}$ and $\mathrm{Zn}$ in the soil of Qianling closed mine. Therefore, factor 4 resolved to the traffic source.

The main load elements of factor 5 were $\mathrm{Zn}(67.8 \%)$, $\mathrm{Pb}$ (65.3\%), and $\mathrm{Cr}$ (55.9\%) ( Fig. 5e). The vehicle emissions were cumulative sources of $\mathrm{Cu}$ and $\mathrm{Zn}$; The fuel combustion, gasoline additives, and engine led to $\mathrm{Pb}$ emissions [46]. The high concentrations of $\mathrm{Cr}$ were related to industrial activities, and industrial waste treatment, sewage sludge, spills and residues all led to $\mathrm{Cr}$ enrichment [47]. The evaluation and correlation analysis of soil heavy metal pollution showed that the pollution level of $\mathrm{Zn}$ in the mining area was the highest compared with other elements, and there was a strong positive correlation between $\mathrm{Zn}$ and $\mathrm{Pb}$, and a significant correlation between $\mathrm{Zn}$ and $\mathrm{Cr}$. Before the mine closure, the emissions from coal combustion, coal chemical industry, coal electricity metallurgy and other industrial activities caused soil $\mathrm{Zn}, \mathrm{Pb}, \mathrm{Cr}$ pollution. Therefore, industrial emissions were the possible pollution sources of $\mathrm{Zn}, \mathrm{Pb}$ and $\mathrm{Cr}$.

According to the factor fingerprints of each heavy metal element, the contribution proportion of each pollution source was calculated, as shown in Fig. 6. The industrial emissions contributed the most to soil heavy metals $(42.08 \%)$, followed by natural source $(22.51 \%)$, atmospheric dust source $(22.47 \%)$, traffic source (8.90\%), and agricultural pollution source (4.04\%). In short, human activities were the dominant factors, which $77.49 \%$ of the pollution was caused by human factors, especially coal mining, coal combustion, coal chemical industry and other industrial activities were the main sources of heavy metals pollution in the study area.

\section{Conclusions}

The conclusions drawn from this research suggested that the average contents of $\mathrm{Zn}, \mathrm{Mn}, \mathrm{As}, \mathrm{Cd}$ and $\mathrm{Pb}$ exceeded the background values of surface soil in Anhui Province. Compared with the soil in Sudong, Sunan and Linhuan mining areas, it is found that the closed mines had significantly higher $\mathrm{Pb}$ and $\mathrm{Zn}$ contents. It was estimated that there were $\mathrm{Pb}$ and $\mathrm{Zn}$ pollution in the surface soil of the closed mine. The assessment results of pollution and ecological risk of soil showed that the closed coal mine was in the mild to moderate pollution and mild hazard ecological risk, in which $\mathrm{Zn}$ pollution degree was the largest, followed by As. The Pearson correlation and positive matrix decomposition model were applied to identify the sources of soil heavy metals, which were atmospheric dustfall $(22.47 \%)$, natural factors $(22.51 \%)$, agricultural activities $(4.40 \%)$, transportation $(8.90 \%)$ and industrial emissions (42.08\%), respectively, of which $77.49 \%$ were related to human activities.

\section{Acknowledgements}

This article is funded by the Key natural science research projects of Suzhou University (2020yzd03, 2020yzd07, 2019yzd01) and National Natural Science Foundation of China (41773100, 41373095).

\section{Conflict of Interest}

The authors declare no conflict of interest.

\section{References}

1. YUAN L., JIANG Y.D., WANG K., ZHAO Y.X., HAO X.J., XU C. Precision exploitation and utilization of closed/ abandoned mine resources in China. Journal of China Coal Society, 43 (01), 14, 2018.

2. REN H., WU G.Q., ZHANG G.C., NING S.Z., ZHU S.F., WANG X.J., HE X.L., LIANG Y.P. The Situation Analysis and Strategy Research of Closed / Abandoned Mine Resources Comprehensive Utilization in China. Coal Geology of China, 31 (02), 1, 2019.

3. XUE D.H. Evaluation and Management of Impact of Closed Mine on Adjacent Production Mines. Coal Technology, 39 (03), 107, 2020.

4. ZHANG P., ZHANG J.P., WANG J. Research on Openpit Coal Mine Geological Environment Problems and Governance Program. Coal Technology, 35 (01), 320, 2016.

5. LI H.Z., ZHA J.F., YUAN Y.F. Research Status and Prospect of Hazards Caused by Close Coal Mine. Safety in Coal Mines, 46 (05), 201, 2015.

6. XU D.J., SHAO D.S. Analysis of hydro logic geology effects induced by closure of local small mines within state-owned mine areas. China Coal, 40 (04), 41, 2014.

7. YANG J., WANG N. Assessment of Potential Ecological Risk of Heavy Metals in Soils from Jia-Pi-Gou Gold Mine Area, China. Journal of Agro-Environment Science, 32 (03), 595, 2013.

8. DAI B., LÜ J.S., ZHAN J.C., ZHAN J.C., ZAHNG Z.L., LIU Y., ZHOU Y.J. Assessment of Sources, Spatial Distribution and Ecological Risk of Heavy Metalsin Soils 
in a Typical Industry-based City of Shandong Province, Eastern China. Environmental science, 36 (02), 507, 2015.

9. LIU S., WU Q.Y., CAO X.J., WANG J.N., ZHANG L.L., CAI D.Q., ZHOU L.Y., LIU N. Pollution Assessment and Spatial Distribution Characteristics of Heavy Metals in Soils of Coal Mining Area in Longkou City. Environmental science, 37 (01), 270, 2016.

10. ZHANG K., YANG J.J., BAI L., QIANG C.L., WANG S.D. The characteristics and source apportionment of heavy metal pollution in the soil at a coal chemical industry area in northwest China. Journal of Mining Science and Technology, 2 (02), 191, 2017.

11. LIU W., YANG J.J., WANG J., WANG G., CAO Y.E. Contamination Assessment and Sources Analysis of Soil Heavy Metals in Opencast Mine of East Junggar Basin in Xinjiang. Environmental Science, 37 (05), 1938, 2016.

12. SUN H., ZHOU C.C., XU Z.Y., WANG X.M. LIU G.J. Spatial distribution and environmental assessment of heavy metals in soil of Huaibei Mining Area. Journal of China University of science and technology, 48 (07), 560, 2018.

13. HUANG D.W., GUI H.R. Sources Analysis and Content Characteristics of Soil Heavy Metal in Sunan Mining Area, China. Earth and environment, 45 (05), 5464, 2017.

14. XIONG S.,GUI H.R.,PENG W.H. Study on heavy metal pollution characteristics of farmland soil in mining area. Journal of Suzhou University, 31 (12), 102, 2016.

15. FANG S.X. Pollution and health risk assessment of heavy metals in soil around a smelter in ChangqingTown of Baoji City. Environment Monitoring and Assessment, 33 (4), 121, 2015.

16. AI J.C., WANG N., YANG J. Source apportion-ment of soil heavy metals in jiapigou goldmine based on the UNMIX model. Environmental Science, 35 (9), 3530, 2014.

17. WANG Q., XIE Z.Y., LI F.B. Using ensemble models to identify and apportion heavy metal pollution sources in agricultural soils on a local scale. Environmental Pollution, 206 (11), 227, 2015.

18. LUO X.S., XUE Y., WANG Y.L., CANG, L., XU, B., DING, J. Source identification and apportionment of heavy metals in urban soil profiles. Chemosphere, 127 (5), 152, 2015.

19. YAO D.X. Comparison research on No4.6 coal seam thickness and mineable test mining of Qian ling coal mine in Anhui. Coal Technology of Northeast China, 2 (4), 3, 1999.

20. FANG T., XIE G.A., WANG B., ZHANG Q.L., XIE S.Y., ZHOU X. Structural characteristics and formation mechanism of Huaibei coalfield. Coal Geology and Exploration, 45 (03), 1, 2011.

21. GUO X.X., LIU C.Q., ZHU Z.Z., WANG Z.L., LI J. Evaluation method of heavy metal pollution in soil. Chinese Journal of Ecology, 30 (05), 889, 2011.

22. FANG S.X., GAN Z.T., LI M.J., ZHANG Z.Q., ZHOU Q. Progress of Assessment Methods of Heavy Metal Pollution in Soil. Chinese Agricultural Science Bulletin, 26 (17), 310,2010

23. LAMINE B.M., YOUCEF H., ALI L. Concentration, Distribution, and Potential Aquatic Risk Assessment of Metals in Water from Chott Merouane (Ramsar Site), Algeria. Archives of Environmental Contamination and Toxicology, 77 (1), 127, 2019

24. LI Z.Y., MA Z.W., YUAN Z.W., HUANG L. A review of soil heavy metal pollution from mines in China, Pollution and health risk assessment. Science of the Total Environment, 468-469, 843, 2014.
25. China National Environmental Monitoring Centre. Background values of soil elements in China.China Environmental Science Press, China, 342, 1990.

26. HAKANSON LARS. An ecological risk index for aquatic pollution control.a sedimentological approach. Water. Res, $\mathbf{1 4}, 975, \mathbf{1 9 8 0}$.

27. IMIN B., ABLIZ A., SHI Q.D., LIU S.H., KAMUS N., LI H. Pollution and source identification of heavy metals in surrounding soils of Eastern Junggar Coalfield based on PMF model. Transactions of the Chinese Society of Agricultural Engineering, 35 (09), 185, 2014.

28. Ministry of Ecology and Environment, PRC, \& State Administration for Market Regulation,Soil environmental quality Risk control standard for soil contamination of agricultural land (GB15618-2018), 2018.

29. CHANG Y.H., ZHAO Y.Y., CAO C., SHAN C., CAO Q. Characteristics of heavy metals and assessment of health risk in different media of in the Dexing Copper Mine Area. Acta geologica Sinica, 89 (05), 889, 2015.

30. YUAN, X.T., ZHANG C.L. Characteristics of Heavy Metal Content in Farmland Soils in Coal Mining Areas of Suzhou City, Environmental Chemistry, 30 (08), 1451, 2011.

31. HUANG D.W., GUI H.R. Distribution features and internal relations of heavy metals in soil-maize system of mining area, Anhui Province, Eastern China, Hum. Ecol. Risk. Assess, 25 (3-4), 863, 2019.

32. FANG H.X., GUI H.R., YU H., LI J., WANG M.C, JIANG Y.Q., WANG C.L. CHEN C. Characteristics and source identification of heavy metals in abandoned coal-mining soil, a case study of zhuxianzhuang coal mine in huaibei coalfield (anhui, china). Human and Ecological Risk Assessment, 16 (3), 1, 2020.

33. XIONG S., GUI H.R., LIN M.L.,PENG W.H. Contents and pollution characteristics of heavy metals in soil from coal mining area, a case study in Linhuan mining district, northern Anhui Province, Fresenius Environmental Bulletin, 26, 1989, 2017.

34. WANG S., HU G.R., YU R.L., YU W.H., ZHOU C.F. Pollution assessment and source analysis of heavy metals in surface sediments from Jiulong River Estuary. Research of Environmental Sciences, 27 (10), 1110, 2014.

35. HORVÁTHA M., VLADISLAVA B., HELTAI G., FLÓRIÁN K., FEKETE I. Study of application of BCR sequential extraction procedure for fractionation of heavy metal content of soils, sediments, and gravitation dusts [J]. Toxicological \& Environmental Chemistry Reviews, 92 (3), 429, 2010.

36. GUO X., ZHEN C.G., CHEN D. Characterization of Arsenic Emissions from a Coal-Fired Power Plant. Environmental science. 04, 631, 2006.

37. BHUIYAN M.A.H., DAMPARE S.B., ISLAM M.A., SUZUKI S. Source apportionment and pollution evaluation of heavy metals in water and sediments of Buriganga River, Bangladesh, using multivariate analysis and pollution evaluation indices. Environmental monitoring and assessment, 187 (1), 4075, 2015.

38. SPIERS G. Trace element content of selected fertilizers and dairy manures as determined by ICPeMS. Commun. Soil Sci. Plant Anal. 32, 139, 2001.

39. MA W.C., TAI L.Y., QIAO Z., ZHONG L., ZHEN W., FU K.X., AND CHEN G.Y. Contamination source apportionment and health risk assessment of heavy metals in soil around municipal solid waste incinerator, A case study in North China. Science of the Total Environment, 631/632, 348, 2018. 
40. BEGUM B.A., BISWAS S.K., HOPKE P.K. Key issues in controlling air pollutants in Dhaka, Bangladesh. Atmospheric Environment, 45 (40), 7705, 2011.

41. PANT P., HARRISON R.M. Critical review of receptor modelling for particulate matter, A case study of India. Atmospheric Environment, 49 (3), 1, 2012.

42. HJORTENKRANS D., BERGBAECK B.O., HAEGGERUD A. New metal emission patterns in road traffic environments. Environmental Monitoring \& Assessment, 117 (1-3), 85, 2006.

43. CHENG Z., CHEN L.J., LI H.H., LIN J.Q., YANG Z.B., YANG Y.X., XU X.X., XIAN J.R., SHAO J.R., ZHU X.M. Characteristics and health risk assessment of heavy metals exposure via household dust from urban area in chengdu, china. Science of the Total Environment, 619-620, 621, 2017.

44. YUEN J.Q., OLIN P.H., LIM H.S., BENNER S.G., SUTHERLAND R.A., ZIEGLER A.D. Accumulation of potentially toxic elements in road deposited sediments in residential and light industrial neighborhoods of Singapore. Journal of Environmental Management, 101 (2), 151, 2012.

45. JAIN S., SHARMA S.K., CHOUDHARY N., MASIWAL R., SHARMA C. Chemical characteristics and source apportionment of PM2.5 using PCA/APCS, UNMIX, and PMF at an urban site of Delhi, India. Environmental ence \& Pollution Research, 24 (17), 1, 2017.

46. ZHAO L., XU Y.F., HOU H., SHANGGUAN, Y.X, LI, F.S. Source identification and health risk assessment of metals in urban soils around the Tanggu chemical industrial district, Tianjin, China [J]. Science of the Total Environment, 468/469, 654, 2014.

47. CHEN H.Y., TENG Y.G, LU S.J, WANG Y.Y, WU J., WANG, J.S. Source apportionment and health risk assessment of trace metals in surface soils of Beijing metropolitan, China [J]. Chemosphere, 144, 1002, 2016. 
